\title{
Intrapelvic migration of the antirotation screw from a short proximal femoral nail: an unusual complication of a usually used implant
}

\author{
Ashutosh Mohapatra, ${ }^{1}$ Priyam Choudhury ${ }^{2}$
} Mohapatra Hospital, Ulhasnagar, India

${ }^{2}$ Department of Radiology, DY Patil Vidyapeeth Dr. DY Patil Medical College and Hospital, Pimpri, Maharashtra, India

\section{Correspondence to}

Priyam Choudhury, priyamchoudhury28@gmail.com

Accepted 8 March 2019
'Department of Orthopaedics,

\section{DESCRIPTION}

A 52-year-old woman met with a fall at home and was brought to our trauma centre. The patient presented with severe, excruciating pain in the left hip. Physical examination of the left hip joint revealed the following findings: tenderness and swelling over the trochanteric region with restricted range of movements and a healed suture mark over the trochanteric region. Further inquiry revealed that the patient had sustained a left hip fracture 3 months previously for which she was operated

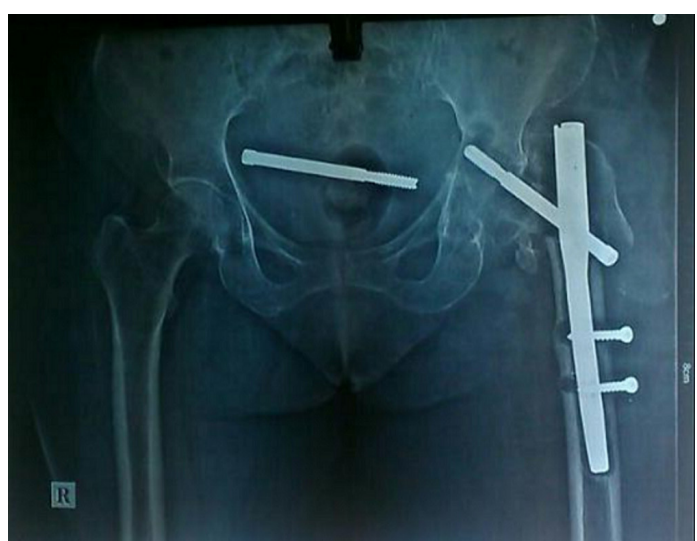

Figure 1 Digital radiograph (anterior posterior view) of the pelvis showing intrapelvic migration of the antirotation screw with varus angulation and non-union at the fracture site. Partial lateral cutting out of the distal locking screws can be seen too.

\section{Learning points}

Shot proximal femoral nail is the popular choice of treatment for pertrochanteric fractures.

Check for updates

(c) BMJ Publishing Group Limited 2019. No commercial re-use. See rights and permissions. Published by BMJ.

To cite: Mohapatra $\mathrm{A}$, Choudhury P. BMJ Case Rep 2019;12:e228713. doi:10.1136/bcr-2018228713

- Cutting out of the lag screw is a common complication, but cutting out leading to intrapelvic migration is a rare complication, and the patient should be assessed for any other pelvic injuries as a consequence of the cutting out.

- Antirotation screw migration into the pelvis is unheard of and has not been reported previously. elsewhere. However, no documentation was available with her. The distal neurovascular status was normal, and the other orthopaedic or systemic findings were clinically irrelevant. Digital radiograph (anterior posterior view) of the pelvis revealed an intrapelvic migration of the antirotation screw from a short gamma 3 nail with varus angulation and non-union at the fracture site (figure 1). An emergency ultrasound of the abdomen and pelvis revealed no intra-abdominal or visceral injuries. An elective surgery in the form of antirotation screw removal+implant (short gamma nail) removal+total hip replacement was planned. Preoperative fitness was obtained, and the patient was successfully operated. Currently (5 weeks postrevision surgery), the patient is doing well and is able to walk without a walker.

The short proximal femoral nail is widely used for the treatment of trochanteric fractures and is considered as a first-choice option for internal fixation of pertrochanteric fractures. ${ }^{1}$ Though cutting out of the lag screw is a common complication, cutting out leading to the medial migration of the screw into pelvis is rare with only a few cases published to date. ${ }^{2}$ As per our knowledge, this is the first case of an intrapelvic antirotation screw migration from a short proximal femoral nail.

Contributors AM: conception, drafting of article and searching the literature for important intellectual content. PC approved the final version.

Funding The authors have not declared a specific grant for this research from any funding agency in the public, commercial or not-for-profit sectors.

Competing interests None declared.

Patient consent for publication Obtained.

Provenance and peer review Not commissioned; externally peer reviewed. 
Copyright 2019 BMJ Publishing Group. All rights reserved. For permission to reuse any of this content visit https://www.bmj.com/company/products-services/rights-and-licensing/permissions/

BMJ Case Report Fellows may re-use this article for personal use and teaching without any further permission.

Become a Fellow of BMJ Case Reports today and you can:

- Submit as many cases as you like

- Enjoy fast sympathetic peer review and rapid publication of accepted articles

Access all the published articles

- Re-use any of the published material for personal use and teaching without further permission

For information on Institutional Fellowships contact consortiasales@bmjgroup.com

Visit casereports.bmj.com for more articles like this and to become a Fellow 